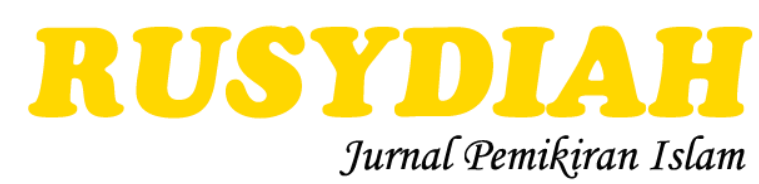

Volume 2 Nomor 1, Juni 2021

ISSN: 2723-4894 (cetak), ISSN: 2723-4886 (daring)

DOI: https://doi.org/10.35961/rsd.v2i1.266

\title{
ARUS PANTEISME JABARIYAH DALAM MASA PANDEMI COVID-19
}

\author{
Nur Ikhlas \\ Dosen Ilmu Hadis STAIN SAR Kepri \\ nurikhlas@stainkepri.ac.id \\ Martunus Rahim \\ Dosen IAIN Kerinci \\ martunus rahim@gmail.com
}

\begin{abstract}
Abstrak
Penelitian ini membahas suatu aliran teologi Islam yaitu jabariyah dengan mendeskripsikan sejarah kemunculann, konsep ketuhanan dan respon terhadap era pandemi covid-19. Sebuah aliran yang lebih berpaham kepada bahwa Qada Qadar adalah suatu hal yang sudah ditentukan Allah SWT, maka sebagai manusia hanya bisa menjalani setiap takdir yang sudah Allah tentukan kepada setiap masing-masing manusia. Dengan menggunakan metode pengumpulan data-data dari berbagai karya literatur buku, majalah, jurnal, berita, dan tulisan-tulisan terkait. Setelah dikaji dapat disimpulkan bahwa menurut pandangan Jabariyah akal dan logika tidak berfungsi dalam hal apapun, karena semua yang ada serta apapun yang terjadi di dunia ini adalah taqdir serta kehendak dari Allah swt. Maka manusia tugasnya hanyalah menerima apapun pemberian dari Allah swt serta menguatkan keimanan dengan beramal ibadah, dan taat kepada Qada dan Qadar yang Allah berikan karena apapun pemberian-Nya adalah suatu anugerah dan hikmah yang patut disyukuri.
\end{abstract}

Kata kunci: Teologi; Jabariyah; Covid-19.

\begin{abstract}
This research discusses a stream of Islamic theology, namely Jabariyah describe of the history of its emergence, the concept of divinity and the response to the Covid-19 pandemic era. A school that understands that Qada Qadar is something that has been determined by Allah Almighty, then as a human being can only live every destiny that Allah has determined for each human being. By using the method of collecting data from various literary works of books, magazines, journals, news, and related writings. After studying it, it can be concluded that according to Jabariyah's view, reason and logic do not function in any way, because everything that exists and whatever happens in this world is destiny and the will of Allah SWT. So the task of humans is only to accept whatever gift from Allah
\end{abstract}


swt and strengthen faith by doing worship, and obey the Qada and Qadar that Allah gives because whatever His gift is a gift and wisdom to be grateful for.

Keywords: Theology, Jabbariyah, Covid-19.

\section{PENDAHULUAN}

Sebuah virus menghebohkan terjadi pada akhir tahun 2019 tepatnya pada bulan Desember, virus ini muncul di Wuhan China yang disebut juga dengan virus corona, Organisasi yang bergerak di bidang kesehatan dunia yaitu World Health Organization (WHO) menyebutkankan virus ini dengan nama CoronaVirus Diseases 2019 disingkat menjadi Covid-19. ${ }^{1}$ Tidak berapa lama dari awal kemunculannya, dunia ikut heboh dan dikejutkan karena semakin merebaknya covid-19 hampir ke seluruh penjuru dunia, tidak dapat dihindari virus tersebut juga menyebar cepat di Indonesia.

Meskipun pemerintah telah mengeluarkan edaran kebijakan mengenai virus corona, salah satu lembaga independen yaitu Majelis Ulama Indonesia yang disingkat dengan MUI yang berada di pusat mengeluarkan fatwa mengenai aturan penyelenggaraan tata cara beribadah selama masa wabah covid-19. Edaran MUI tersebut keluar tak selang berapa lama virus corona merambak ke Indonesia, ${ }^{2}$ hal ini dilakukan sebagai salah satu bentuk upaya MUI menaungi umat terhindar dari bahaya virus corona, yang mana lembaga ini adalah lembaga persatuan cendekiawan Islam, Ulama-ulama agar mengayomi, membimbing dan membina khusus untuk umat Islam Indonesia. Adapun isi kebijakan fatwa yang di edarkan yaitu panduan beribadah dan tata pelaksanaannya karena virus ini mewabah berhubung dengan masuknya bulan suci Ramadhan. Namun, meski MUI sudah menegeluarkan edaran tersebut tetap saja bagi beberapa kalangan di masyarakat tidak mengindahkannya dan masih melaksanakan ibadah seperti biasa.

Dengan berbagai alasan seperti memelihara tradisi, mempererat silaturahmi persaudaraan, meningkatkan ketaatan ibadah dan alasan lainnya berbagai macam kegiatan. Beberapa organisasi Islam yang bergerak di lembaga dakwah masih tetap mengadakan pertemuan di masa pandemic covid-19, baik itu pertemuan di tingkat nasional maupun Internasional. Pertemuan yang dilaksanakan menuai

1 Yan-Rong Guo, 'The Originm Transmission and Clinical Therapies on Coronavirus Disease 2019 (COVID-19) Outbreak-Update on the Sratus', Militery Medical Research, 2020.

2 Lembaga Komisi Fatwa Majelis Ulama Indonesia (MUI) Nomor: 14 Tahun 2020 tentang Penyelenggaraan Ibadah Dalam Situasi Terjadi Wabah Covid-19 yang diketuai oleh Prof. Dr. H. Hasanuddin Af, Sekretaris Dr. HM. Asrorun Ni'Am Sholeh, M.A dan diketahui oleh Dewan Pimpinan MUI Wakil ketua Umum KH. Muhyiddin Junaedi, M.A dan Sekjend Dr. H. Anwar Abbas, M.M, M. Ag 
kontroversial di kalangan masyarakat dan menimbulkan polemic. Bahkan tidak sedikit dari mereka merespon dengan membawa problematika tersebut ke ranah teologi dan mengaitkannya dengan pemahaman mengenai takdir baik dan takdir buruk. Edaran yang dikeluarkan oleh pemerintah dan MUI dalam menghadapi kondisi wabah covid-19 sebagai salah satu usaha yang dilakukan untuk memutuskan mata rantai menyebarnya virus akan sangat berpengaruh berhasil atau tidaknya dalam praktek aliran teologi ini yaitu Jabariyah.

Sebagai umat muslim, terjadinya wabah yang melanda dunia tidak bisa terlepas dari Qada, Qadar dan Takdir karena semua mempunyai hubungan pertalian awal mula sebab munculnya Covid-19. Sebelum memasuki pembahasan terlebih dahulu kita pahami tentang Qada, Qadar dan takdir. Dalam al-Qur'an surat Fushshilat ayat 10:

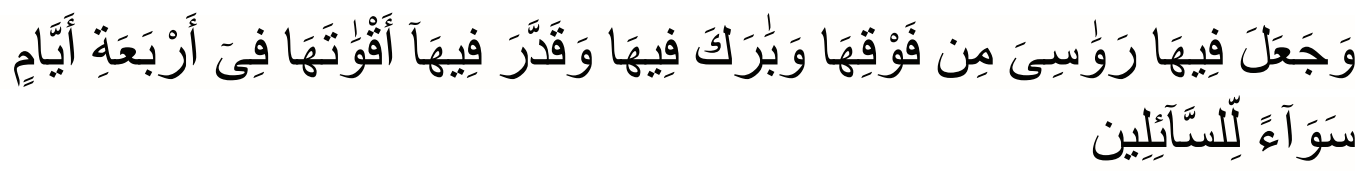

"Dan dia menciptakan di bumi itu gunung-gunung yang kokoh di atasnya. Dia memberkahinya dan Dia menentukan padanya kadar makanan-makanan (penghuni)nya dalam empat masa. (Penjelasan itu sebagai jawaban) bagi orangorang yang bertanya".

Menurut salah seorang tokoh ilmu kalam KH Taib Thahir mengatakan penggunaan kata Qada' dalam al-Qur'an memaknai qada' dengan hukum yang sudah ditetapkan Tuhan sejak zaman azali terhadap segala sesuatu yang akan terjadi kedepannya. Adapun Qadar adalah keputusan yang sudah terjadi sesuai ilmu serta takdir Tuhan sejak zaman azali. Dalam tulisannya Dja'far Amir mengatakan bahwa Takdir adalah suatu ketentuan Allah yang mesti berlaku terhadap semua mahkluk, sesuai dengan batasan yang sudah ditentukan Tuhan sejak dari zaman azali, baik itu ketentuan yang baik maupun ketentuan yang buruk. Takdir pasti akan terjadi sesuai dengan kadar yang dikehendaki Tuhan. ${ }^{3}$

Sebab terjadinya pandemi wabah virus corona atau covid-19 di wuhan dan menular ke Indonesia mengandung maksud bahwa segala sesuatu itu tanpa terkecuali sudah ditakdirkan dan ditetapkan oleh Allah 'Azza wa Jalla. Oleh karena itu, manusia tidak bisa terhindar dan terlepas dari yang sudah Allah

\footnotetext{
${ }^{3}$ Arifin Jami'an, Memahami Takdir (Gresik: CV Bintang Pelajar, 1986).
} 
tentukan. Sehingga yang dapat dituntut sebagai hamba Allah hanyalah bagaimana dia bersikap terhadap takdir Allah tersebut, hadirnya virus corona menurut Jabariyah merupakan sebuah takdir Allah. Dalam pandangannya tidak mungkin terjadi segala sesuatu di bumi Allah sampai hari ini, kecuali sudah direncanakanNya.

Menurut mereka adanya virus corona atau covid-19 merupakan siksa Tuhan yang diganjarkan kepada manusia bagi mereka yang lalai dan melanggar larangan agama, juga azab bagi kaum kafir. Ujian bagi kaum muslimin yang sabar serta tawakkal atas kehendak Allah, karena bagi mereka yang patuh dengan ketentuan takdir Allah akan menambah keimanan bagi mereka.

Dalam agama Islam ada beberapa macam bentuk dalam cara merespon dan menyikapi takdir Allah. Pertama, yaitu kaum yang menafikan takdir mereka beranggapan bahwa tidak ada yang namanya takdir. Kedua, kaum yang cukup berlebihan dalam menyikapi takdir sehingga segala sesuatu baik yang belum maupun yang sudah terjadi itu bagi mereka adalah takdir, maka dari itu manusia tidak perlu lagi berusaha ataupun berikhtiar dalam menjalani hidup. Terkahir yaitu kaum yang mengatakan bahwa segala sesuatu itu sudah Allah takdirkan, akan tetapi manusia tetap harus berusaha dan bertawakkal kepada-Nya sehingga apapun hasilnya setelah semua usaha sudah dilakukan adalah ketetapan dari Allah swt.

Dari tiga golongan kaum di atas dalam menyikapi takdir jika dikaitkan dengan tanggapan mengenai virus covid-19 dapat diasumsikan bahwa ada tiga macam cara kaum muslim memahami takdir. Ada yang hanya pasrah berserah diri kepada Allah swt dengan tidak mematuhi dan tidak mengindahkan aturan dari pemerintah. Selain itu dalam melaksanakan ibadah mereka juga tidak melaksanakan aturan dari fatwa MUI, demikian juga dengan pesan-pesan anjuran dari tenaga medis. Cara mereka bersikap ini tentunya berlandaskan dengan hadis dan dalil yang mereka yakini dan tak ayal dalil yang mereka gunakan juga ada dari hadis yang hukumnya dha'if bahkan bernilai mawdhu'.

Berlandaskan dari timbulnya permasalahan di atas, penulis akan mengkaji lebih dalam lagi dan melakukan analisa tentang bagaimana respon penganut paham aliran teologi Jabariyah mengenai aturan surat yang diedarkan pemerintah dan MUI tentang covid-19 sebagai salah satu upaya penghentian dan pemutusan mata rantai virus corona.

Ilmu pengetahuan tentang ketuhanan mengenai sifat Allah SWT, dasar dan landasan kepercayaan kepada Allah dan Agama terutama berdasarkan kitab 
sucinya yang disebut dengan Teologi Islam merupakan suatu kenyataan sejarah yang tidak dapat disangkal keberadaannya. Istilah kata teologi diambil dari khazanah dan tradisi kristiani, ${ }^{4}$ pembahasan suatu ajaran pokok atau suatu teori ilmu yang berkaitan dengan Tuhan berarti disebut juga dengan teologi. Sejarah lahirnya teolog Islam berawal dari doktrin agama Islam itu sendiri yang terbagi kepada dua cabang, yaitu akidah dan syariat.

Pada dasarnya kepercayaan aqidah merupakan aspek teori yang mesti diyakini dan tidak ada keraguan lagi akan kebenarannya oleh penganut umat muslim. Dan hukum syari'at adalah aspek landasan dalam praktek beramal dalam kehidupan sehari-hari, karena syari'at Islam berisikan aturan 'amali mulai dari hubungan dengan Tuhan sebagai penciptanya, hubungannya dengan alam semesta, juga hubungannya dengan alam semesta.

Mengkaji masalah sejarah teologi, tidak terlepas dari kajian Ilmu Kalam karena merupakan salah satu cabang ilmu yang tidak bisa dipisahkan dari teologi, ilmu kalam yang pada dasarnya adalah ilmu yang membahas tentang Aqidah dan ke-imanan manusia terhadap Tuhannya. Adanya perbedaan pemikiran-pemikiran kaum teolog tak dapat dipungkiri bahwa perbedaan tersebut menyebabkan munculnya persoalan-persoalan teologi dalam Islam, ${ }^{5}$ semua itu dipicu oleh persoalan politik. Meskipun pada awalnya yang menjadi pokok permasalahannya menyangkut keabsahan kekuasaan politik akan tetapi bergeser pada teologi dan menyebabkan timbulnya aliran-aliran teologi Islam.

Mempelajari teologi akan memberikan gambaran yang konkrit tentang aliran-aliran yang ada dalam Islam, orang yang telah mempelajari teologi dia mampu menjelaskan secara rinci terhadap teologi itu sendiri dia juga memiliki keyakinan yang susah untuk digoyahkan. Teologi yang sudah dipelajari menjadikannya kuat untuk berpegang teguh dengan landasan sebagai pedoman akan keterikatannya dengan Tuhan.

Karena banyaknyanya terjadi perdebatan interen yang berkepanjangan tak berkesudahan baik itu perbedaan dalam praktis maupun teoritis sehingga lahirlah beberapa aliran dalam islam diantaranya, Murji'ah, Khawarij, Mu'tazilah, Qadariya dan Jabariyah.

4 Djohan Effendi, Konsep-Konsep Teologi: Kontekstualisasi Doktrin-Doktrin Islam Dalam Sejarah (Jakarta: Paramadina, 1994).

${ }^{5}$ Said Agil Al-Munawar and Husni Rahim, Teologi Islam Regional (Aplikasi Terhadap Wacana Dan Praktis Harus Nasution) (Jakarta: Ciputat Press). 
Salah satu paham teologi yang akan dibahas dalam tulisan ini adalah teologi Jabariyah. Dalam hal ini peneliti tidak menguraikan penyebab perbedaan aliran-aliran tersebut, melainkan menjelaskan sejarah timbulnya aliran Jabariyah di dunia Islam, ajaran-ajaran Jabariyah, tokoh-tokohnya serta respon aliran teologi Jabariyah dalam menghadapi wabah virus Covid-19.

\section{METODE}

Adapun kajian yang dilakukan dalam penelitian ini yaitu kajian yang berdasarkan literature-literatur dari hasil karya berupa buku, jurnal, artikel, berita dan hal-hal yang berkaitan dengan pembahasan teologi Jabariyah dan Covid 19. Sedangkan sumber data yaitu dari data sekunder dan data primer sesuai dengan kebutuhan pokok yang diperlukan dalam penulisan.

Teknik pengumpulan data dengan cara library research atau kepustakaan yaitu mengadakan studi menelaah buku-buku, literature-literatu, catatan serta laporan yang berhubungan dengan pemecahan masalah. Membaca, mempelajari literatur-literatur yang berkaitan dengan obyek penelitian.

Agar memudahkan dalam mendapatkan pemahaman yang lebih luas dan mendalam mengenai situasi kondisi sosial yang diteliti, maka penulis berinisiatif melakukan teknik mengumpulkan data dilakukan bersifat triangulasi. Yaitu menggunakan berbagai teknik pengumpulan data secara gabungan/stimultan. ${ }^{6}$ Langkah-langkah yang di ambil yaitu orientasi atas bacaan, pengumpulan data melalui dokumen, menganalisis data, dan hasil berupa kesimpulan.

\section{HASIL DAN PEMBAHASAN}

\section{A.Sejarah Timbulnya Aliran Jabariyah}

Jabariyah $^{7}$ lahir murni sebagai suatu paham gerakan teologi, berbeda halnya dengan aliran selain Jabariyah yang timbul karena dorongan politik seperti aliran Khawarij dan Syi'ah. Bibit paham Jabariyah sudah ada semenjak periode pertama Islam, namun karena aliran yang masih baru maka baru

6 Sugiyono, Metode Penelitian Kuantitatif Kualitatif Dan ReðD (Bandung: Alfabeta, 2013).

${ }^{7}$ Kata Jabariyah berasal dari bahasa arab "جبر" yang berarti memaksa. Dalam kamus Al-munjid dijelaskan nama Jabariyah kata "jabara” yang mengandung arti memaksa dan mengharuskannya untuk melakukan sesuatu. Louwis Ma’luf, Al-Munjid Fi Al-Lughah Wa Al-Alam (Beirut: Dar Al-Masyria, 1998). 
berkembang pada era Dinasti Bani Umayyah (660-750 M) di Syiria. ${ }^{8}$ Yakni pada masa situasi kondisi keadaan keamanan lingkungan masyarakat yang sudah pulih ditandai dengan keberhasilan tercapainya perjanjian antara Muawiyah dengan Hasan bin Ali bin Abu Thalib, yang pada masa itu sudah tidak mempunyai kemampuan lagi untuk menghadapi kekuatan Muawiyah.

Dengan demikian maka kelompok Muawiyah mencarikan solusi dan jalan tengah untuk memperkuat dan mempertahankan kedudukannya. Ia ingin memasukkan ke dalam pikiran rakyat bahwa pengangkatannya sebagai kepala Negara dan memimpin umat Islam adalah berdasarkan "Qadha dan Qadar" dan tidak ada unsur kekuatan manusia yang terlibat di dalamnya. Muawiyah berkata: "Kalau Allah tidak rida kepadaku, tidak mungkin aku menjadi khalifah wakil pengganti Nabi: maka, jikalau Allah swt membenciku, niscaya Allah akan menggantikanku dengan yang lain." 9

Munculnya aliran Jabariyah didorong oleh kondisi masyarakat Arab yang sangat bergantung secara keseluruhan kepada Alam. Aliran ini tidak berdaya berhadapan dengan ganasnya serta terik matahari di gurun sahara dan akhirnya mendorong mereka untuk pasrah diri kepada alam. ${ }^{10}$ Ditengah teriknya panas matahari hamparan pasir dan sedikitnya sumber mata air tidak mendukung untuk tumbuhnya tumbuhan dan pepohonan hijau, dengan demikian paham jabariyah merasa tidak mempunyai kemampuan mengubah kondisi untuk bisa hidup semestinya sebagaimana yang mereka inginkan. oleh karena itu mereka berserah diri dan menerima keadaan dalam kondisi apapun. Mereka merasa lemah tidak mempunyai kekuatan daya upaya dalam menghadapi kesukaran-kesukaran hidup. Dalam artian mereka banyak bergantung dengan Alam, sehingga menyebabkan mereka kepada paham fatalisme.

Menganut paham bahwasannya manusia melakukan tindakan dan perbuatannya dalam keadaan terpaksa dan tidak punya pilihan lain, segenap tindakan dan perbuatannya itu pada dasarnya sudah ditentukan sedemikian rupa oleh Allah SWT semenjak Azali atau berkekalan. Dalam bahasa lain paham ini disebut juga dengan paham fatalistic atau presdetination. ${ }^{11}$

\footnotetext{
${ }^{8}$ Huwaidhy, Dirasat Fi Ilmi Al-Kalam Wa al-Falsafah al-Islamiyah (Kairo: Dar Ats-Tsaqafah, 1980).

${ }^{9}$ Rumadi, Renungan Santri Dari Jihad Hingga Wacana Agama (Jakarta: Erlangga, 2006).

${ }_{10}$ Ahmad Amin, Fajr Al-Islam (Kairo: Maktabah an-Nahdah al-Misriyah li Ashbiha Hasan Muahammad wa Awladih, 1924).

11 Muhammad Amin Suma, 'Kelompok Dan Gerakan', in Ensiklopedi Tematis Dunia Islam (Jakarta: PT Ichtiar Baru Van Hoeve).
} 
Paham jabariyah awalmulanya diperkenalkan oleh Ja'ad bin Dirham lalu kemudian disebarluaskan oleh Jahm bin Shufwan dari Khurasan. Masa perkembangan berikutnya paham al-jabar juga dikembangkan oleh tokoh lain yang bernama al-Husain bin Muhammad An-Najjar dan Ja'ad bin Dirrar. ${ }^{12}$

Benih pemahaman teologi aliran Jabariyah terbilang sudah cukup lama munculnya jauh sebelum dicetus oleh dua orang tokoh di atas, hal ini ditandai ketika Nabi Muhammad Rasulullah saw menjumpai sahabat yang kala itu sedang berselisih paham dan bertengkar memperdebatkan persoalan takdir Tuhan. Nabi lalu melarang mereka dan tidak boleh ada perdebatan dan perbincangan mengenai takdir Allah, agar mereka terlepas dari kesalahpahaman penjelasan penafsiran mengenai ayat-ayat Tuhan khususnya tetang takdir. ${ }^{13}$

Hal itu dilarang Nabi karena adanya indikasi kehati-hatian menafsirkan ayat Allah dalam menentukan takdir yang sudah ditentukan Tuhan. Maka hal ini dianalisa bahwa aliran Jabariyah melihat manusia tidak bisa campur tangan dalam penentuan takdir. ${ }^{14}$

Ayat-ayat suci al-Qur'an di atas terkesan bahwa takdir ada di tangan Tuhan. Membawa seseoraang kedalam alam pikiran aliran Jabariyah. Dalam karyanya buku ilmu kalam, Thaib Thahir mengatakan bahwasannya paham ini disebabkan oleh karena kuatnya iman terhadap qudrat (kuasa) dan iradat (berkehendak) Allah ditambah pula dengan sifat wahdaniyat Esa-nya itu yang memotivasi kepada paham Jabaraiyah. ${ }^{15}$ Sehingga menimbulkan kepercayaan juga keyakinan yang kuat bahwa qudrat dan iradat adalah hak Allah.

Terlepas dari bibit-bibit dan dalil-dalil ayat al-Quran yang mendukung lahirnya paham Jabariyah, pendapat lain berpendapat bahwa aliran Jabariyah

\footnotetext{
${ }^{12}$ Harun Nasution, Teologi Islam: Aliran-Aliran Sejarah Analisa Perbandingan (Jakarta: UI Press, 1972).

${ }^{13}$ Aziz Dahlan, Sejarah Perkembangan Pemikiran Dalam Islam (Jakarta: Beuneuubi Cipta, 1987).

${ }^{14}$ Dalam Alquran ayat yang mendukung sebagai landasan paham Jabariyah diantaranya Q.S. As-Saffat: 96:

$$
\text { وَ اللَهُ خَلَقَكُمْ وَمَا تَعْمَلُوْنَنَ }
$$

Artinya: "Padabal.Allah-lah yang menciptakan kamu dan apa yang kamu perbuat itu". (Q.S. As-Saffat:96).

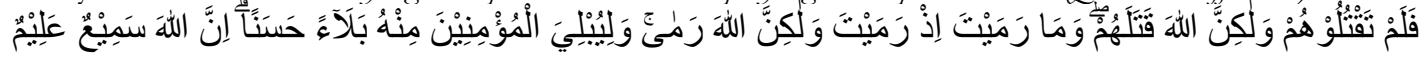
Artinya: "Maka (yang sebenarnya) bukan kamu yang membunub mereka, akan tetapi Allablah yang membunuh mereka, dan bukan kamu yang melempar ketika kamu melempar, tetapi Allah-lah yang melempar. (Allah berbuat demikian untuk membinasakan mereka) dan untuk memberi kemenangan kepada orang-orang mukmin, dengan kemenangan yang baik. Sesunggubnya Allah Maba mendengar lagi Maha mengetabui". (Q. S. Al-Anfal: 17)

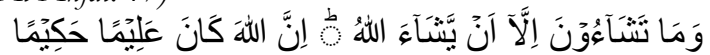

Artinya: "Dan kamu tidak mampu (menempuh jalan itu), kecuali bila dikehendaki Allah. Sesunggubnya Allah adalah Maha mengetabui lagi Maba Bijaksana”. (Q.S. Al-Insan: 30)

${ }_{15}$ Abdul Mun'im Thaib Thahir, Ilmu Kalam (Jakarta, 1986).
} 
muncul disebabkan karena adanya pengaruh daya yang timbul dari pemikiran asing, yaitu pengaruh agama Yahudi bermazhab Qurra dan agama Kristen bermazhab Yacobit. ${ }^{16}$ Dapat kita analisa bahwa lahirnya paham ini tidak hanya dipengaruhi oleh permasalahan dalam situasi dan kondisi agama Islam itu sendiri akan tetapi juga dari luar agama Islam.

Disamping itu, munculnya pemahaman Jabariah ini menjadi alasan dasar terkuat sebagai respon dari gejala kejadian peristiwa adanya paham teologi Qadariyah dan terlalu tekstual dalam memahami tek-teks agama serta tidak ada keberanian untuk menakwilkan dan memaminya secara kontekstual. Karena tidak semua teks agama bisa dipahami secara tekstual, adakalanya membutuhkan pemahaman kontekstual sebagai penguat dari apa yang dimaksud teks.

\section{B. Konsep Ketuhanan Jabariyah}

Jabariyah yaitu orang yang menafikan perbuatan manusia secara hakikat dari seorang hamba dan menyandarkan perbuatan kepada Rabb, maksudnya adalah menyerahkan sepenuhnya kepada takdir Allah SWT tanpa adanya ikhtiar atau usaha.

Dalam aliran Jabiyah, terdapat dua jabaran ajaran paham ini:

1. Aliran ekstrim.

2. Aliran moderat.

Dua ajaran ini menjadi pokok dalam amalan beribadah kepada Allah swt, adapun penjelasan dari dua ajaran aliran ekstrim dan moderat tersebut akan diuraikan dibawah.

Pertama aliran ekstrim, Salah satu tokoh Aliran ekstrim ini adalah Jahm bin Sofyan. Beliau adalah da'i yang pintar menjabat sebagai sekretaris Harits bin Surais. Beberapa ajaran Jahm dalam teologi ini bahwa manusia tidak mampu berbuat apa-apa semua tidak akan terjadi kecuali atas kehendak Allah, adapun surga dan neraka kelak tidak kekal abadi, Iman adalah ma'rifat dan dibenarkan dalam hati, dan Kalam Tuhan adalah makhluk.

Tokoh aliran ekstrim Jabariyah lainnya selain Jahm bin Soyfan adalah Ja'ad bin Dirham, beliau berpendapat Al-Qur'an adalah makhluk dan sebagai makhluk Allah manusia terpaksa melakukan hal apapun oleh Allah SWT.17

${ }^{16}$ Sahiludin A.Nasir, Pengantar Ilmu Kalam (Jakarta: Rajawali, 1991).

${ }^{17}$ Rosihan Anwar, Ilmu Kalam (Bandung: Pustaka Setia, 2006). 
Setiap perbuatan manusia Allah ciptakan dalam dirinya dan manusia diciptakan dengan keadaan terbelenggu serta tidak mempunyai kemampuan dan kebebasan untuk menentukan pilihan dalam menjalani hidup mereka baik itu secara individual maupun kelompok.

Perbuatan-perbuatan, sikap, dan tingkah laku yang Allah ciptakan untuk setiap makhluknya tidak ada beda dan ubahnya sama sekali dengan gerak gerik yang Allah ciptakan pada benda yang tidak bergerak atau benda mati. Maka dari itu, manusia ciptaan Tuhan dalam berbuat bukan diartikan sebagai bentuk majazi. Semua perilaku dan perbuatan manusia itu adalah perbuatan yang dipaksa termasuk perbuatan melakukan amalan kewajiban, menerima reward sebagai ganjaran pahala dan juga siksaan. ${ }^{18}$

Segala perbuatan tingkah laku manusia menurut paham ekstrim ini bukanlah perbuatan yang muncul dari keinginan dirinya sendiri, namun adalah perbuatan yang dipaksakan atas kehendak dirinya. Apapun bentuk pergerakan manusia baik usaha, ikhtiar dan segala bentuk upaya yang dilakukannya itu semua diyakini sebagai gerakan yang digerakkan oleh Tuhan. Tanpa gerakan yang dizinkan oleh Tuhan manusia tidak punya kuasa untuk berbuat apa-apa.

Ajaran lain yang dikemukakan dalam paham ekstirm ini ialah bahwa Allah swt tidak mempunyai sifat selain zat-Nya itu sendiri. Tujuan peniadaan dari sifat ini adalah agar ke-Maha Esa-an Tuhan tetap benar-benar utuh, sempurna tanpa ada rusak, perubahan dan kekurangan, sebab seandainya Allah swt memiliki sifat, maka dengan sendirinya pada zat-Nya terdapat "sesuatu yang lain" yang melekat pada zat tersebut. Hal demikian akan dapat menjurus pada adanya kemajemukan pada zat Allah SWT. Sifat-sifat Allah SWT yang digambarkan dalam Al-Quran, seperti Maha Mendengar (sami') dan Maha Melihat (basir), tidak harus dipahami secara hafiah, akan tetapi harus ditakwilkan, karena sifat-sifat semacam itu serupa dengan makhluk, dan hal itu sangat mustahil bagi Allah SWT, karena Allah SWT tidak memiliki keserupaan dengan makhluk, dan makhlukpun tidak dapat menyerupai-Nya. ${ }^{19}$

Kedua, aliran moderat. Aliran ini dipelopori oleh al-Husain Ibn Muhammad al-Najjar, beliau mengatakan Tuhanlah yang menciptakan perbuatan-perbuatan, tingkah laku manusia yang baik maupun perbuatan yang jahat. Tokoh yang juga menyebarkan ajaran moderat ini adalah Adh-Dhirar

\footnotetext{
18 Al-Syahrastaniy, Al Milal Wa Al Nihal (Kairo: Dar al-Fikr).

${ }^{19}$ Muhammad Amin Suma.
} 
Ibnu 'Amr, ia berpendapat bahwa perbuatan-perbuatan manusia pada hakekatnya diciptakan Tuhan. ${ }^{20}$

Tenaga yang ada pada manusia merupakan ciptaan yang diberikan Tuhan sebagai bentuk efek dari apa yang mereka lakukan, karena manusia hanya mempunyai bagian perwujudan dalam perbuatannya. Dengan demikian hal inilah yang dimaknai dengan istilah kasb atau dalam bahasa inggris disebut juga dengan acquisition..$^{21}$ Dalam ajaran modern dikatakan bahwa manusia ada pengaruh terhadap Tuhan Allah SWT atas perbuatan yang diperbuat.

Dalam ajaran Jabariyah yang moderat, manusia tidak dipaksa melakukan apapun tidak seperti pertujukan wayang yang dikendalikan oleh dalang dan tidak pula menjadi pencipta perbuatan. Akan tetapi manusia memperoleh perbuatan yang diciptakan Tuhan. Manusia punya andil dalam mewujudkan perbuatannya seolah-olah ada kerja sama Tuhan dengan manusia.

Jika kita pahami lagi uraian-uraian dari pendapat di atas dapat di asumsikan bahwasannya di satu sisi tingkah laku perbuatan manusia ditentukan oleh Allah SWT, namun di sisi lain segala perbuatan manusia tidak sepenuhnya ada ikut campur tangan manusia akan tetapi ada juga kuasa atas perbuatannya.

\section{Perkembangan Jabariyah}

Paham Jabariyah sudah terlihat benihnya di Zaman Nabi, hal ini terlihat ketika terjadiny aperdebatan di antara para sahabat mengenai Qadar bahw aTuhan adalah merupakan salah satu indicator penyebab Qadar. Rasulullah saw menyuruh Umatnya agar beriman kepad takdir, namun melarang membicarakan perihal takdir secara mendalam..$^{22}$

Aliran golongan paham Jabariyah untuk pertama kalinya muncul di daerah Khurasan Persia beriringan dengan saat munculnya paham dari golongan Qadariyah yang diperkirakan saat itu tahun tujuh puluh (70) $\mathrm{H}$. Teologi ini dipelopori oleh Jahm bin Shafwan. Nama Jabariyah dinisbatkan kepada Jahm bin Shafwan, maka dari itulah alasan kelompok Jabariyah disebut dengan kaum Jahmmiyah.

Kemudian dalam perkembangan selanjutnya, kelompok dari paham Jabariyah ini disebut sebagai yang menganut paham lama, konservatif dan

20 Al-Syahrastaniy.

21 Al-Syahrastaniy.

22 Ali Mustafa al-Ghurabi, Tarikh Al-Firaq al-Islamiyah (Kairo: Maktabah wa Matb'ah Muhammad Ali Sabih wa Alaudin). 
tradisional disebabkan karena tetap ingin mempertahankan keadaan kebiasaan, dan tradisi sudah ada dan berlaku pada masyarakat sebelumnya. Peluang semangat untuk mengadakan investigasi sangat rendah, karena semua peristiwa yang terjadi dianggap sudah suatu kehendak yang dilakukan Allah SWT.

Periode berikutnya aliran ini masih berkelanjutan dan bergulir saling mempengaruhi dari setiap generasi ke generasi kebawah, namun secara zhahir hampir tidak dijumpai lagi. Dalam teologis pemahamannya Jabariyah tidak terlalu banyak berpengaruh pada kehidupan sosial masyarakat secara umum, namun lebih banyak berpengaruh kepada keyakinan kehidupan individualis.

\section{D.Kelompok Yang Menolak Jabariyah}

Kaum Jabariyah berkesimpulan makhluk Allah terlebih manusia dengan rasa keterpaksaan berbuat di luar kemauannya sendiri karena terdesak oleh keadaan, maka dari itu mau tidak mau harus menerima dan tidak bisa memilih terhadap perbuatannya. Ibarat bulu yang ditup angin terombang-ambing sampai mendarat ditempatnya. Sehingga kaum Jabariyah tidak berbuat dan tidak melakukan apa-apa dengan hujjah takdirnya.

Keyakinan tersebut membawa dampak kepada penolakan untuk berbuat kebaikan, meninggalkan amal shalih amar ma'ruf dan tidak mempedulikan penegakan hukum, Karena sudah beranggapan bahwa kejahatan merupakan takdir yang pasti akan terjadi dan tidak dapat ditolak. Sehingga hanya dapat menerima apapun bentuk hal yang akan terjadi, karena telah ditakdirkan dan dikehendaki oleh Allah swt.

Anggapan seperti ini bahwa manusia tidak mempunyai kekuasaan sama sekali telah disangkal oleh ulama penganut Ahlu Sunnah wal Jamaah, mereka memahami keimanan terhadap takdir yang Allah tentukan tidak berlawanan dengan kepercayaan bahwa manusia punya kehendak dan bisa memilih atas perbuatan yang mereka inginkan, mereka juga mempunyai kemampuan untuk melakukannya.

Adapun dalil Alquran yang dikemukakan oleh ulama Ahlul Sunnah wal jamaah di antaranya Q. S. An-Naba' 39 :

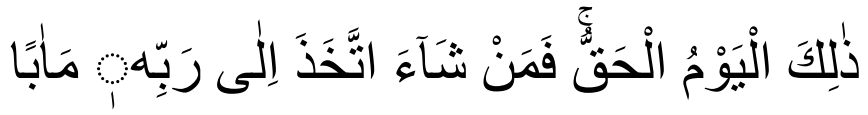

"Itulah hari yang pasti terjadi. Maka Barangsiapa yang menghendaki, niscaya ia menempuh jalan kembali kepada Tuhannya". (Q. S. An-Naba' 39) 


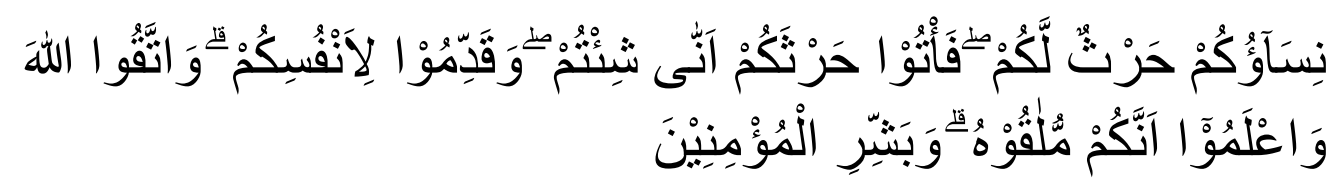

"Isteri-isterimu adalah (seperti) tanah tempat kamu bercocok tanam, Maka datangilah tanah tempat bercocok-tanammu itu bagaimana saja kamu kehendaki. dan kerjakanlah (amal yang baik) untuk dirimu, dan bertakwalah kepada Allah dan ketahuilah bahwa kamu kelak akan menemui-Nya. dan berilah kabar gembira orang-orang yang beriman". (Q.S. Al-Baqarah: 223).

Manusia yang sudah mencapai usia baligh dan berakal menurut tandatanda yang ada dalam Islam seperti hal nya bagi laki-laki perubahan suara, mimpi basah, dan bagi perempuan datangnya masa haidh. Manusia dengan kriteria ini sudah menyadari dia punya keinginan serta mampu untuk berkehendak, dan meninggalkan apa yang tidak ingin dia kehendaki. Manusia yang baligh juga sudah bisa menyatakan perbedaan apa yang terjadi atas dirinya dan mana yang bukan terjadi karena dirinya. Sehingga dirinya merasa bertanggungjawab terhadap sesuatu yang sudah terjadi atau lepas tanggungjawab terhadap apa tidak dilakukan.

\section{KESIMPULAN}

Dari paparan dan penjelasan di atas dapat dipahami paham Jabariyah berpandangan bahwa manusia sebagai makhluk ciptaan Allah sama sekali tidak punya kuasa atas sikap, perbuatan dan tingkah lakunya dan yang berhak terhadap itu semua hanyalah Allah swt. Uraian mengenai takdir, Qadha dan Qadhar dalam teologi Jabariyah serta segala yang terjadi pada hamba-Nya di dunia merupakan kuasa dan Kehendak dari Allah swt tanpa adanya peran ikut campur dari manusia termasuk juga perbuatan maksiat. Perbuatan manusia diibaratkan dengan dedaunan yang jatuh dari pohonnya lalu diterpa angin.

Dalam konteks wabah penyakit virus corona atau Covid-19 kelompok Jabariyah menyikapi dengan sikap santai dan tidak takut corona, sehingga ketika ada aturan dari pemerintah, MUI, dan ormas-ormas terkait aturan protokol kesehatan yang selalu dicanangkan yaitu mencuci tangan, memakai masker dan 
menjaga jarak maka mereka tidak akan patuh dengan alasan tidak takut virus corona dan satu-satunya yang patut di takuti serta dipatuhi hanyalah Allah SWT.

Bagi Jabariyah makhluk hidup tidak mempunyai hak untuk menyanggah apapun ketentuan dan ketetapan Tuhan. Allah swt pencipta alam semesta punya hak untuk mengadili dan menuntut apapun yang sudah diperbuat oleh makhluknya. Umat manusia tidak memiliki kesanggupan untuk memahami ilmu Allah swt, hanya Dia satu-satunya yang dapat mengetahui apa hikmah dan tujuan atas segala yang Allah ciptakan. Dengan begitu kuatnya keimanan teologi Jabariyah akan kuasa dan kehendak (Qudrat \& Iradat) Allah 'Azza wa Jalla, hal inilah yang mereka jadikan motivasi dalam ajaran keyakinannya.

Sebagai salah satu teologi dalam Islam, satu hal yang dapat dipahami dan dimengerti dari paham teologi Jabariyah bahwasannya aliran ini mengemukakan sebab-sebab, dalil-dalil serta alasan kuat agar terbebas dari kesesatan dalam beragama. Sehingga apa yang dituju dalam beragama hanyalah ingin mendapatkan keridhaan, kemuliaan, keberkahan dan kesucian dari Allah SWT dengan sesempurnanya iman.

\section{DAFTAR PUSTAKA}

Abdul Mun'im Thaib Thahir, Ilmu Kalam (Jakarta, 1986)

Ahmad Amin, Fajr Al-Islam (Kairo: Maktabah an-Nahdah al-Misriyah li Ashbiha Hasan Muahammad wa Awladih, 1924)

Ali Mustafa al-Ghurabi, Tarikh Al-Firaq al-Islamiyah (Kairo: Maktabah wa Matb'ah Muhammad Ali Sabih wa Alaudin)

Al-Syahrastaniy, Al Milal Wa Al Nihal (Kairo: Dar al-Fikr)

Arifin Jami'an, Memahami Takdir (Gresik: CV Bintang Pelajar, 1986)

Aziz Dahlan, Sejarah Perkembangan Pemikiran Dalam Islam (Jakarta: Beuneuubi Cipta, 1987)

Djohan Effendi, Konsep-Konsep Teologi: Kontekstualisasi Doktrin-Doktrin Islam Dalam Sejarah (Jakarta: Paramadina, 1994)

Harun Nasution, Teologi Islam: Aliran-Aliran Sejarah Analisa Perbandingan (Jakarta: UI Press, 1972) 
Huwaidhy, Dirasat Fi Ilmi Al-Kalam Wa al-Falsafah al-Islamiyah (Kairo: Dar AtsTsaqafah, 1980)

Louwis Ma'luf, Al-Munjid Fi Al-Lughah Wa Al-Alam (Beirut: Dar Al-Masyria, 1998)

Muhammad Amin Suma, 'Kelompok Dan Gerakan', in Ensiklopedi Tematis Dunia Islam (Jakarta: PT Ichtiar Baru Van Hoeve)

Rosihan Anwar, Ilmu Kalam (Bandung: Pustaka Setia, 2006)

Rumadi, Renungan Santri Dari Jihad Hingga Wacana Agama (Jakarta: Erlangga, 2006)

Sahiludin A.Nasir, Pengantar Ilmu Kalam (Jakarta: Rajawali, 1991)

Said Agil Al-Munawar and Husni Rahim, Teologi Islam Regional (Aplikasi Terhadap Wacana Dan Praktis Harus Nasution) (Jakarta: Ciputat Press)

Sugiyono, Metode Penelitian Kuantitatif Kualitatif Dan RED (Bandung: Alfabeta, 2013)

Yan-Rong Guo, 'The Originm Transmission and Clinical Therapies on Coronavirus Disease 2019 (COVID-19) Outbreak-Update on the Sratus', Militery Medical Research, 2020. 